\title{
A taxonomy of hydrological processes and watershed function
}

\author{
Hilary McMillan ${ }^{1}$ \\ ${ }^{1}$ San Diego State University
}

September 25, 2021

\begin{abstract}
This paper presents a taxonomy (hierarchical organization) of hydrological processes; specifically, runoff generation processes in natural watersheds. Over 120 process names were extracted from a literature review of papers describing experimental watersheds, perceptual models, and runoff processes in a range of hydro-climatic environments. Processes were arranged into a hierarchical structure, and presented as a spreadsheet and interactive diagram. For each process, additional information was provided: a list of alternative names for the same process, a classification into hydrological function (e.g. partitioning, flux, storage, release) and a unique identifier similar to a hashtag. The taxonomy provides a method to label and search hydrological knowledge, thereby facilitating synthesis and comparison of processes across watersheds.
\end{abstract}

\section{Introduction}

Hydrological processes describe the movement of water through watersheds, as part of the hydrological cycle. Any hydrologist is familiar with these processes, such as infiltration, evapotranspiration, or groundwater flow. Through field experiments, hydrologists have named more specific processes, such as interflow, macropore flow or fill-and-spill. These processes fall within the broader term "watershed function", defined as "the actions of the catchment on the water entering its control volume" (Wagener et al., 2007). Building on earlier frameworks (Black, 1997; McDonnell and Woods, 2004; Soulsby et al., 2006), Wagener et al. (2007) classify catchment function into partitioning, storage and release of water.

Previous frameworks largely have the goal of catchment classification: determining clusters of catchment function that can be predicted using physical characteristics such as soils, land-use, topography, etc. Recently, community interest in open data has led to further work on organizing hydrological information, for example in the CUAHSI Hydrologic Information System (CUAHSI-HIS). A significant development is HY_features, a "Surface Hydrology Features Conceptual Model", and part of the Open Geospatial Consortium WaterML 2.0 standard for online water data (Almoradie et al., 2013). HY_features describes hydrological and hydrographic features (e.g. waterbodies, observations) and their relationships. It can be used to describe river networks for GIS and modelling applications (Blodgett et al., 2021) and builds on previous work on ontologies for hydrology (Stephen and Hahmann, 2017).

These previous frameworks, however, do not explicitly list the types of processes (e.g. macropore flow) that hydrologists use when describing runoff generation. There are many applications that would benefit from a standard list of processes, such as labelling and searching hydrological descriptions to compare processes and synthesize knowledge across sites, collating watershed information for machine learning ground-truth, and providing descriptors in perceptual models to share hydrological knowledge and identify gaps (Wagener et al., 2020). These needs echo those of the biological sciences to provide systematic nomenclature for plants and animals (Linnaeus, 1758). Writing in Nature for Linnaeus' 300 ${ }^{\text {th }}$ anniversary, Godfray (2007) reminds us that "to understand anything in science, things have to have a name that is recognized and is universal".

Therefore, this technical note describes a taxonomy (hierarchical organization) of hydrological processes, including primary and alternative names. The taxonomy is designed to augment textual watershed descrip- 
tions with a summary of the constituent processes. As in biological taxonomy, future revision and expansion is expected. For example, to limit the scope, we focused on processes in natural watersheds that might be included in a typical runoff generation model. We do not include process definitions, and direct the reader to appropriate glossaries and encyclopaedia sources (WMO, 2012; NSIDC, 2021; Anderson and McDonnell, 2005). These glossaries do not however include all the specialist terms used by catchment hydrologists. Future work might include more detailed treatment of specific environments (e.g. cold regions) and expansion to additional environments and domains (e.g. wetlands, water quality, deep groundwater, human influences on hydrology).

\section{Method}

Our investigation was structured by process class (Anderson and McDonnell, 2005), for example "evapotranspiration", "overland flow", or "groundwater flow". McMillan (2020) provided a list of papers describing processes in experimental watersheds. We searched literature on perceptual models, including recent discussions of perceptual model use and scope (Beven and Chappell, 2021; Wagener et al., 2021), perceptual models of well-known watersheds such as Panola (Aulenbach et al., 2021), Maimai (McGlynn et al., 2002) and the Attert Basin (Wrede et al., 2015), and perceptual models of specific processes such as infiltration (Beven, 2004). Many papers do not explicitly refer to perceptual models but equivalently describe runoff generation processes. We surveyed these papers with particular attention to studies from a wide range of climate and landscape types. These included arid (Ries et al., 2017), humid (Dunne and Black, 1970; Hewlett and Hibbert, 1967), cold region (Peters et al., 1995; Pomeroy et al., 1999; Quinton and Marsh, 1999; Rango, 1993), forested (Bonell, 1993; Jones, 2000), and karst watersheds (Hartmann et al., 2013).

From each paper, we extracted all names or short phrases describing runoff generation processes. Where available, we referred to previous process classifications such as the typology of groundwater-surface water interaction by Dahl et al. (2007), and processes in earth system models (Clark et al., 2015; Fan et al., 2019). We noted alternative names for each process, although it was sometimes difficult to ascertain minor differences in meaning between terms; see further comment in the Discussion section below.

To integrate the new taxonomy with previous classification systems, we specified a functional class for each process. Bracken et al. (2013) divided hydrological function into structural knowledge - to do with stores and process-based knowledge - to do with fluxes. Wagener's classification (2007) adds partitioning andrelease. We added a class Complex process for emergent behaviors, and subcategories of each class were added as needed (Table 1).

The process taxonomy was collated into spreadsheet format that tracked the hierarchical structure by assigning a 'parent' to each process name (see Supplemental Information). The spreadsheet was processed in $R$ using the collapsible Tree package to create an interactive tree diagram (Khan et al., 2018). Processes were shown as nodes that expand and collapse, and were coloured by functional class. Tool tips displayed alternative names and the identifier.

\section{Results}

Our investigation returned over 120 named processes; see the supplementary material for a complete list. Processes could be satisfactorily arranged into a hierarchical structure, with an initial division into surface, subsurface and channel processes, and a maximum of five underlying layers. Some processes had ambiguity in their position, for example transient saturation at the bedrock interface could fall into soil or groundwater processes categories. Processes often had many alternative names, for example runoff generation by displacement of groundwater is also referred to as pipeflow, pistonflow, old water mobilization, pre-event water mobilization, translatory flow, pressure wave and hydraulic displacement.

Each process was assigned a unique identifier, similar to a hashtag. The identifiers use dots to signify hierarchical level, with each level given a text tag of at most six characters. Thus, change in grain size during snowpack aging is classified as Surface - Snow and Cold Region Processes - Snow Storage - Snowpack Aging - Change in grain size, with the identifier Surf.Cold.Snow.Age.Grain. This provides a short reference 
string for any process. If a different hierarchical structure is used in future, it would be relatively simple to remap the identifiers.

Some names could be disputed as representing stores rather than processes, and might be classed as a physical entity in an ontological framework. However, water storage has long been regarded as part of watershed function, and was therefore included in the taxonomy. Functional classes are listed in Table 1, and give more detail than previous classifications, for example differentiating between 'store', 'filling of store' and 'release from store'. For example, snowmelt is designated as 'release from store' as only the origin store is specified. We created an interactive version of the taxonomy that can be accessed at http://mcmillanhydrology.org/ProcessTaxonomy/ProcessTaxonomyDiagram.html . A view of the interactive taxonomy with overland flow processes expanded is given in Figure 1.

When hydrologists described watershed function, a variety of information types were provided. Information could relate to the existence or magnitude (of stores, fluxes), spatial variation (location), temporal variation (seasonal variation or wetness conditions for processes to occur or stores to fill), or response time. These types could be used as an additional descriptor of hydrological information when stored in a database or similar.

\section{Example Application}

McGlynn et al. (2002) provide a comprehensive description of hydrological processes in the Maimai watershed in New Zealand. Their article concludes with a list of processes at the site. We used this summary to demonstrate how textual process descriptions could be mapped onto our taxonomy. Table 2 gives each description from the article, and maps it to each level of the process hierarchy. The final column encodes the type of information (magnitude, spatial variation, temporal variation or response time). By tagging each text string with the taxonomical name, this information could be more easily compared with descriptions of other watersheds, or other sources of information about the same watershed.

\section{Discussion}

\section{Hydrological process descriptions in journal articles}

We found that information about processes could be difficult to extract from journal articles. Descriptions were often complex and multi-faceted, with multiple processes described in one sentence. Process interpretations were mixed with narrative text on observations, and description of observations often dominated process inference. Such text makes process information slower to extract and re-use. With an increasing emphasis on synthesis of process understanding across sites (Jackisch et al., 2021), efforts to increase data sharing are important. We recommend the process summary in McGlynn et al. (2002; see Table 2) as an example of good practice. The article has a separated section that lists the dominant runoff processes in the watershed. However, we recognize the difficulty of summarizing process information that facilitates re-use without losing important detail.

\section{Alternative process names}

In our investigation, we commonly found multiple names for the same or very similar process. This plurality has been discussed in the literature, e.g. Weiler et al. (2006) write that

"Subsurface stormflow is also known in the hydrological literature as interflow, lateral flow, subsurface runoff, transient groundwater, or soil water flow. These multiple terms often confuse the process understanding of subsurface stormflow response to rainfall or snowmelt."

We found that hydrologists sometimes use multiple terms in the same article e.g., through-flow and subsurface saturated flow. It is difficult for the reader to determine whether the authors intended nuanced differences between these terms, or whether they refer to the same process. The same term might also be used with different meanings in different sources, for example throughflow is variously defined as lateral flow in unsaturated or saturated conditions. We recommend that authors consistently use the same process name throughout an article, and define the term where there is a possibility of confusion. 


\section{Conclusion}

This paper introduced a hierarchical organization of hydrological processes, derived from literature review of journal articles describing experimental watersheds, perceptual models and runoff generation processes. The taxonomy includes over 120 named processes, which are recorded alongside their functional type (e.g. storage, flux), alternative names, and a unique identifier. Processes often had multiple alternative names, which can hinder extraction and sharing of hydrological information. We recommend that authors of journal articles use consistent terms for processes throughout, and consider a separate section with succinct process inference information. The taxonomy can promote hydrological information sharing and synthesis by providing a method to label and search process knowledge.

\section{Data Availability Statement}

The taxonomy is available as a spreadsheet, with an $\mathrm{R}$ script to create the interactive diagram, at https://github.com/mcmillanhk/ProcessTaxonomy

\section{References}

Almoradie, A., Jonoski, A., Popescu, I., Solomatime, D., 2013. Web Based Access to Water Related Data Using OGC WaterML 2.0. Int. J. Adv. Comput. Sci. Appl. IJACSA EnviroGRIDS Spec. Issue "Building Reg. Obs. Syst. Black Sea Catchment 83-89.

Anderson, M.G., McDonnell, J.J., 2005. Encyclopedia of hydrological sciences. Wiley

Aulenbach, B.T., Hooper, R.P., van Meerveld, H.J., Burns, D.A., Freer, J.E., Shanley, J.B., Huntington, T.G., McDonnell, J.J., Peters, N.E., 2021. The evolving perceptual model of streamflow generation at the Panola Mountain Research Watershed. Hydrol. Process. 35, e14127.

Beven, K., 2004. Robert E. Horton's perceptual model of infiltration processes. Hydrol. Process. 18, $3447-3460$.

Beven, K.J., Chappell, N.A., 2021. Perceptual perplexity and parameter parsimony. Wiley Interdiscip. Rev. Water 8, e1530.

Black, P.E., 1997. Watershed Functions 1. JAWRA J. Am. Water Resour. Assoc. 33, 1-11.

Blodgett, D., Johnson, J.M., Sondheim, M., Wieczorek, M., Frazier, N., 2021. Mainstems: A logical data model implementing mainstem and drainage basin feature types based on WaterML2 Part 3: HY Features concepts. Environ. Model. Softw. 135, 104927.

Bonell, M., 1993. Progress in the understanding of runoff generation dynamics in forests. J. Hydrol. 150, $217-275$.

Bracken, L.J., Wainwright, J., Ali, G.A., Tetzlaff, D., Smith, M.W., Reaney, S.M., Roy, A.G., 2013. Concepts of hydrological connectivity: Research approaches, pathways and future agendas. Earth-Sci. Rev. 119, 1734. https://doi.org/10.1016/j.earscirev.2013.02.001

Clark, M.P., Fan, Y., Lawrence, D.M., Adam, J.C., Bolster, D., Gochis, D.J., Hooper, R.P., Kumar, M., Leung, L.R., Mackay, D.S., 2015. Improving the representation of hydrologic processes in Earth System Models. Water Resour. Res. 51, 5929-5956.

Dahl, M., Nilsson, B., Langhoff, J.H., Refsgaard, J.C., 2007. Review of classification systems and new multi-scale typology of groundwater-surface water interaction. J. Hydrol. 344, 1-16.

Dunne, T., Black, R.D., 1970. Partial area contributions to storm runoff in a small New England watershed. Water Resour. Res. 6, 1296-1311.

Fan, Y., Clark, M., Lawrence, D.M., Swenson, S., Band, L.E., Brantley, S.L., Brooks, P.D., Dietrich, W.E., Flores, A., Grant, G., 2019. Hillslope hydrology in global change research and Earth system modeling. Water Resour. Res. 55, 1737-1772. 
Godfray, H.C.J., 2007. Linnaeus in the information age. Nature 446, 259-260.

Hartmann, A., Wagener, T., Rimmer, A., Lange, J., Brielmann, H., Weiler, M., 2013. Testing the realism of model structures to identify karst system processes using water quality and quantity signatures. Water Resour. Res. 49, 3345-3358.

Hewlett, J.D., Hibbert, A.R., 1967. Factors affecting the response of small watersheds to precipitation in humid areas. For. Hydrol. 1, 275-290.

Jackisch, C., Hassler, S. K., Hohenbrink, T. L., Blume, T., Laudon, H., McMillan, H., Saco, P., van Schaik, L., 2021. Preface: Linking landscape organisation and hydrological functioning: from hypotheses and observations to concepts, models and understanding. Hydrological and Earth System Sciences, in press.

Jones, J.A., 2000. Hydrologic processes and peak discharge response to forest removal, regrowth, and roads in 10 small experimental basins, western Cascades, Oregon. Water Resour. Res. 36, 2621-2642.

Khan, A., Shah, D., Bostock, M., 2018. Package 'collapsibleTree'. Retrieved from https://cran.rproject.org/web/packages/collapsibleTree/collapsibleTree.pdf.

Linnaeus, C. von, 1758. Systema naturæ per regna tria naturæ, secundum classes, ordines, genera, species, cum characteribus, differentiis, synonymis, locis. Tomus I. Editio decima, reformata. - pp. [1-4], 1-824. Holmiæ. (Salvius).

McDonnell, J.J., Woods, R., 2004. On the need for catchment classification. J. Hydrol. 299, 2-3.

McGlynn, B.L., McDonnel, J.J., Brammer, D.D., 2002. A review of the evolving perceptual model of hillslope flowpaths at the Maimai catchments, New Zealand. J. Hydrol. 257, 1-26.

NSIDC, National Snow and Ice Data Center, 2021. Cryosphere Glossary. Retrieved from https://nsidc.org/cryosphere/glossary

Peters, D.L., Buttle, J.M., Taylor, C.H., LaZerte, Bd., 1995. Runoff production in a forested, shallow soil, Canadian Shield basin. Water Resour. Res. 31, 1291-1304.

Pomeroy, J.W., Granger, R., Pietroniro, A., Elliott, J., Toth, B., Hedstrom, N., 1999. Classification of the boreal forest for hydrological processes, in: Proceedings of the Ninth International Boreal Forest Research Association Conference, Edited by S. Woxholtt. pp. 49-59.

Quinton, W.L., Marsh, P., 1999. A conceptual framework for runoff generation in a permafrost environment. Hydrol. Process. 13, 2563-2581.

Rango, A., 1993. II. Snow hydrology processes and remote sensing. Hydrol. Process. 7, 121-138.

Ries, F., Schmidt, S., Sauter, M., Lange, J., 2017. Controls on runoff generation along a steep climatic gradient in the Eastern Mediterranean. J. Hydrol. Reg. Stud. 9, 18-33.

Soulsby, C., Tetzlaff, D., Dunn, S.M., Waldron, S., 2006. Scaling up and out in runoff process understanding: insights from nested experimental catchment studies. Hydrol. Process. Int. J. 20, 2461-2465.

Stephen, S., Hahmann, T., 2017. An ontological framework for characterizing hydrological flow processes, in: 13th International Conference on Spatial Information Theory (COSIT 2017). Schloss Dagstuhl-LeibnizZentrum fuer Informatik.

Wagener, T., Dadson, S.J., Hannah, D.M., Coxon, G., Beven, K., Bloomfield, J.P., Buytaert, W., Cloke, H., Bates, P., Holden, J., 2021. Knowledge Gaps in our Perceptual Model of Great Britain's Hydrology. Hydrol. Process. e14288.

Wagener, T., Gleeson, T., Coxon, G., Hartmann, A., Howden, N., Pianosi, F., Rahman, S., Rosolem, R., Stein, L., Woods, R., 2020. On doing large-scale hydrology with Lions: Realising the value of perceptual models and knowledge accumulation. 
Wagener, T., Sivapalan, M., Troch, P., Woods, R., 2007. Catchment classification and hydrologic similarity. Geogr. Compass 1, 901-931.

Weiler, M., McDonnell, J.J., Meerveld, I.T., Uchida, T., 2006. Subsurface Stormflow, in: Encyclopedia of Hydrological Sciences. Retrieved from https://doi.org/10.1002/0470848944.hsa119

WMO, W.M.O., 2012. International Glossary of Hydrology, WMO- No. 385. Retrieved from https://library.wmo.int/doc_num.php?explnum_id=8209

Wrede, S., Fenicia, F., Martínez-Carreras, N., Juilleret, J., Hissler, C., Krein, A., Savenije, H.H., Uhlenbrook, S., Kavetski, D., Pfister, L., 2015. Towards more systematic perceptual model development: a case study using 3 Luxembourgish catchments. Hydrol. Process. 29, 2731-2750.

Table 1: Listing of Functional Classes assigned to each named process

\begin{tabular}{ll}
\hline Functional Type & Functional Class \\
\hline Storage & Store \\
& Store, temporary \\
& Store characteristics, temporary \\
& Store characteristics, permanent \\
& Filling of store \\
& Release from store \\
Flux & In-catchment flux \\
& In-store flux \\
Partitioning & Flux between two stores \\
Release & Partitioning between flux types \\
Complex process & Release \\
\hline
\end{tabular}

Table 2: Process Descriptions in the summary section of McGlynn et al.'s (2002) description of processes in the Maimai watershed, New Zealand.

\begin{tabular}{|c|c|c|c|c|c|}
\hline $\begin{array}{l}\text { Description in } \\
\text { Journal } \\
\text { Article }\end{array}$ & Process Type & Process & Sub-process & Sub-process & $\begin{array}{l}\text { Type of } \\
\text { Information }\end{array}$ \\
\hline $\begin{array}{l}\text { High } \\
\text { infiltration } \\
\text { rates well in } \\
\text { excess of } \\
\text { maximum } \\
\text { precipitation } \\
\text { intensities }\end{array}$ & Surface & Infiltration & & & Magnitude \\
\hline $\begin{array}{l}\text { Uniform } \\
\text { wetting front } \\
\text { propagation } \\
\text { with small and } \\
\text { protracted } \\
\text { events }\end{array}$ & Sub-surface & Soils & Matrix flow & Vertical & Temporal \\
\hline
\end{tabular}




\begin{tabular}{|c|c|c|c|c|c|}
\hline $\begin{array}{l}\text { Description in } \\
\text { Journal } \\
\text { Article }\end{array}$ & Process Type & Process & Sub-process & Sub-process & $\begin{array}{l}\text { Type of } \\
\text { Information }\end{array}$ \\
\hline $\begin{array}{l}\text { Two domains } \\
\text { of lateral } \\
\text { throughflow } \\
\text { that include } \\
{[\ldots] \text { slow, }} \\
\text { more uniform } \\
\text { matrix flow }\end{array}$ & Sub-surface & Soils & Matrix flow & Lateral & $\begin{array}{l}\text { Existence, } \\
\text { response time } \\
\text { (qualitative) }\end{array}$ \\
\hline $\begin{array}{l}\text { Vertical } \\
\text { bypass flow to } \\
\text { depth with } \\
\text { large events }\end{array}$ & Sub-surface & Soils & $\begin{array}{l}\text { Macropore } \\
\text { flow }\end{array}$ & & Temporal \\
\hline $\begin{array}{l}\text { Old water } \\
\text { dominated } \\
\text { throughflow } \\
\text { (resident soil } \\
\text { water as } \\
\text { opposed to } \\
\text { new rainfall) }\end{array}$ & Sub-surface & Soils & Mixing & & Spatial \\
\hline $\begin{array}{l}\text { Transient } \\
\text { water table } \\
\text { development } \\
\text { on hillslopes }\end{array}$ & Sub-surface & Groundwater & GW Storage & $\begin{array}{l}\text { Perched water } \\
\text { table }\end{array}$ & Spatial \\
\hline $\begin{array}{l}\text { Topographic } \\
\text { convergence of } \\
\text { water flow into } \\
\text { hollows }\end{array}$ & Sub-surface & Groundwater & GW flow & $\begin{array}{l}\text { Topographic } \\
\text { convergence }\end{array}$ & Spatial \\
\hline $\begin{array}{l}\text { Rapid lateral } \\
\text { throughflow } \\
\text { response to } \\
\text { precipitation } \\
\text { following } \\
\text { threshold } \\
\text { water table } \\
\text { development }\end{array}$ & Sub-surface & Groundwater & GW flow & $\begin{array}{l}\text { Subsurface } \\
\text { stormflow / } \\
\text { Saturated }\end{array}$ & $\begin{array}{l}\text { Temporal, } \\
\text { Response time } \\
\text { (qualitative) }\end{array}$ \\
\hline $\begin{array}{l}\text { Two domains } \\
\text { of lateral } \\
\text { throughflow } \\
\text { that include } \\
\text { rapid (albeit } \\
\text { disconnected) } \\
\text { pipe flow at } \\
\text { the soil } \\
\text { bedrock } \\
\text { interface }\end{array}$ & Sub-surface & Groundwater & GW flow & $\begin{array}{l}\text { Subsurface } \\
\text { stormflow / } \\
\text { Saturated / } \\
\text { soil-bedrock } \\
\text { interface }\end{array}$ & $\begin{array}{l}\text { Spatial, } \\
\text { Response time } \\
\text { (qualitative) }\end{array}$ \\
\hline
\end{tabular}




\begin{tabular}{|c|c|c|c|c|c|}
\hline $\begin{array}{l}\text { Description in } \\
\text { Journal } \\
\text { Article }\end{array}$ & Process Type & Process & Sub-process & Sub-process & $\begin{array}{l}\text { Type of } \\
\text { Information }\end{array}$ \\
\hline $\begin{array}{l}\text { High degree of } \\
\text { throughflow } \\
\text { variability } \\
\text { across } \\
\text { seemingly } \\
\text { planar } \\
\text { hillslopes }\end{array}$ & Sub-surface & Groundwater & GW flow & $\begin{array}{l}\text { Subsurface } \\
\text { stormflow }\end{array}$ & Spatial \\
\hline $\begin{array}{l}\text { Bedrock } \\
\text { topographical } \\
\text { control on the } \\
\text { spatial } \\
\text { distribution of } \\
\text { mobile } \\
\text { subsurface } \\
\text { saturated flow }\end{array}$ & Sub-surface & Groundwater & GW flow & $\begin{array}{l}\text { Subsurface } \\
\text { stormflow }\end{array}$ & Spatial \\
\hline
\end{tabular}

\section{Figure Legends}

Figure 1: Example output from taxonomy diagram, with overland flow processes expanded, and showing tooltip information for Infiltration Excess Flow process.

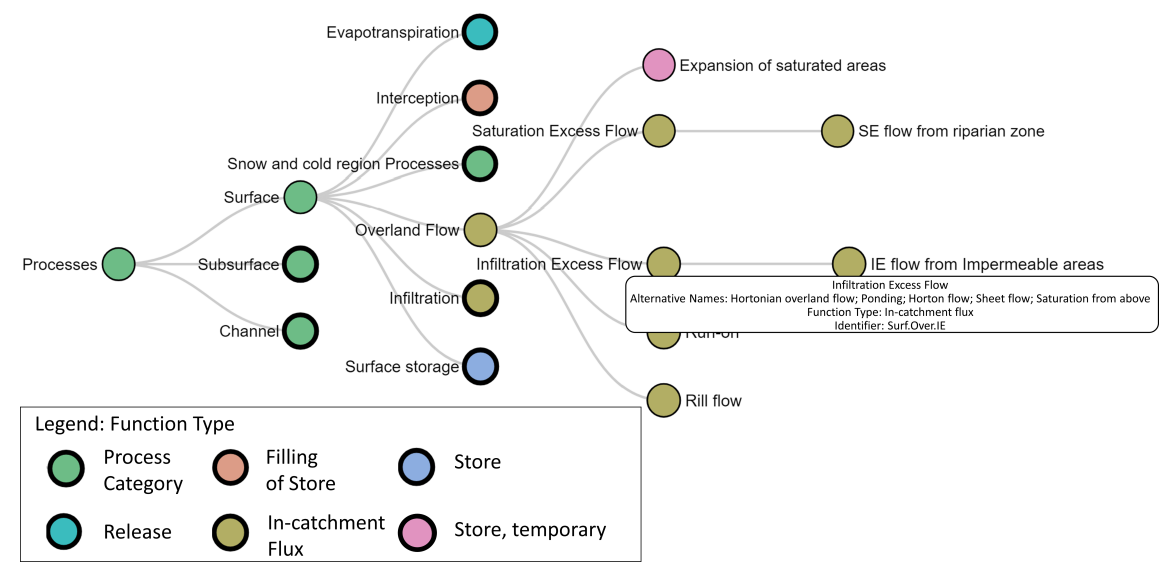

